\title{
透析患者における血清終末糖化産物（AGEs）濃度 一セベラマー塩酸塩少量投与の効果一
}

\author{
村 本 弘 昭 ${ }^{1}$ 武藤 ${\text { 寿 } \text { 生 }^{1} \text { 竹 内 正 義 }}^{2}$ \\ 金沢社会保険病院内科 ${ }^{1}$ 金沢医科大学総合医学研究所先端医療研究領域 ${ }^{2}$
}

キーワード：終末糖化産物（AGEs），セベラマー塩酸塩，慢性腎不全，血液透析

〈要旨〉

終末糖化産物（AGEs）は糖尿病や尿毒症において生成が促進され，血管合併症の発現に深く関与していると考え られている. われわれは既報で炭酸カルシウムからセベラマー塩酸塩に変更することにより血清 AGEs 濃度が低 下し，透析患者の血管合併症が軽減する可能性について報告した. しかし，副作用である便秘は無視できない問題 と考えられ，今回セべラマー塩酸塩の少量投与による血清 AGEs 濃度への影響を検討した. 3 か月以上安定して週 3 回透析を施行している患者 21 例を対象に, 炭酸カルシウム投与量は変更せずセべラマー塩酸塩 $1.5 \mathrm{~g} /$ 日を上乗 せ投与し, 血清 AGEs, 脂質, リン, カルシウムおよびインタクトPTH 值を経時的に検討した. AGEs は食品中に 多く含まれる glucose 由来の Glc-AGEs および生体内で生成され強い毒性を呈する glyceraldehyde 由来の Glycer-AGEs を ELISA 法で測定した. Glc-AGEs は $16.03 \pm 10.53 \mathrm{U} / \mathrm{mL}$ から 24 週後 $5.57 \pm 4.40 \mathrm{U} / \mathrm{mL}$ と有意に低下 した. Glycer-AGEs は開始時の平均值で 2 群に分けて検討したが, 高值群で $8.49 \pm 1.12 \mathrm{U} / \mathrm{mL}$ から 24 週後 6.74 $\pm 0.84 \mathrm{U} / \mathrm{mL}$ と有意に低下し, 低值群では変化を認めなかった. Non-HDL コレステロール值は有意に低下し, $\mathrm{HDL}$ コレステロール值は有意に上昇した. 血清リン值は約 $0.8 \mathrm{mg} / \mathrm{dL}$ 低下し，血清カルシウム値には変化を認め なかった. Glc-AGEs は経口的に体内に取り込まれ強毒性の Glycer-AGEs の産生を増強することが報告されてお り, 血清 AGEs 值の低下はセベラマー塩酸塩による食事中の AGEs の吸着除去効果も考えられるが, そのほかオキ シダントなどさまざまな物質の除去による酸化ストレス軽減も影響している可能性が考えられている. 今回の検討 で, 腹部症状を起こしにくい量のセべラマー塩酸塩投与でも有意な血清 AGEs 值の低下や血清脂質の改善を認め, 透析患者の血管合併症を軽減させる可能性を示した. 生体へのカルシウムの過剰な負荷を避けるためにも，まず基 礎薬として服薬可能な量のセベラマ一塩酸塩を投与することは透析患者にとって十分有用性があると考えられた.

\section{Serum levels of advanced glycation end-products (AGEs) in dialysis patients-Effects of low-dose sevelamer hydrochloride-}

Hiroaki Muramoto', Hisao Mutoh', and Masayoshi Takeuchi ${ }^{2}$

Department of Internal Medicine, Kanazawa Social Insurance Hospital ${ }^{1}$; Department of Advanced Medicine, Medical Research Institute, Kanazawa Medical University ${ }^{2}$

Key words : advanced glycation end-products (AGEs), sevelamer hydrochloride, chronic renal failure, hemodialysis

〈Abstract〉

The formation of advanced glycation end-products (AGEs) is accelerated in the presence of diabetes mellitus and uremia. AGEs have been strongly implicated in the pathogenesis of vascular complications. We previously reported that switching from calcium carbonate to sevelamer hydrochloride lowered serum AGEs levels and led to a reduced risk of vascular complications in dialysis patients. However, constipation is considered to be a nonnegligible adverse effect of sevelamer hydrochloride monotherapy. In this study, we examined the effect of lowdose sevelamer hydrochloride on the serum concentrations of AGEs. Twenty-one patients receiving dialysis three times per week for more than three months were included and sevelamer hydrochloride $(1.5 \mathrm{~g} /$ day $)$ was added

村本 弘昭 金沢社会保険病院内科 $\quad$ \% 920-8610 石川県金沢市沖町八-15

Hiroaki Muramoto Tel : 076-252-2200 Fax : 076-253-5074

〔受付日：2012 年 8 月 31 日, 受理日：2013 年 2 月 12 日〕 
without changing the dose of calcium carbonate. Serum levels of AGEs, lipids, phosphorus, calcium, and intact PTH were measured during the study period. Glucose-derived AGEs (Glc-AGEs), which are normally contained in food, and glyceraldehyde-derived AGEs (Glycer-AGEs), which are generated in vivo and are highly toxic, were measured by ELISA. Serum Glc-AGEs significantly decreased from $16.03 \pm 10.53 \mathrm{U} / \mathrm{mL}$ to $5.57 \pm 4.40 \mathrm{U} / \mathrm{mL}$ after 24 weeks. Patients were divided into two groups depending on their initial mean serum Glycer-AGEs levels. In the high level group, Glycer-AGEs significantly decreased from $8.49 \pm 1.12 \mathrm{U} / \mathrm{mL}$ to $6.74 \pm 0.84 \mathrm{U} / \mathrm{mL}$ after 24 weeks, whereas no significant change was observed in the low level group. Treatment with sevelamer hydrochloride significantly decreased non-HDL cholesterol levels and increased HDL cholesterol levels. Serum phosphorus levels decreased by approximately $0.8 \mathrm{mg} / \mathrm{dL}$, and serum calcium levels were unchanged. It has been reported that GIc-AGEs orally taken into the body subsequently enhance the production of highly toxic GlycerAGEs. The decreased serum AGEs levels may be attributed to the adsorption removal of dietary AGEs as well as a reduction in oxidative stress as a result of the removal of other substances including oxidants by sevelamer hydrochloride. The present study demonstrated that even low-dose sevelamer hydrochloride, which reduces abdominal symptoms, can significantly decrease serum AGEs levels and improve the serum lipid profile. These results suggest that low-dose sevelamer hydrochloride could reduce the risk of vascular complications in dialysis patients. To avoid calcium overload, treatment with low doses of sevelamer hydrochloride as a basal agent may also be beneficial for dialysis patients.

\section{はじめに}

終末糖化産物（advanced glycation end-products : AGEs）はグルコースなどの還元糖とタンパク質との 間の非酵素的糖化反応（発見者の名にちなんでメイ ラード反応とも呼ばれている）の後期段階で生成され る構造体の総称であり, 主として糖尿病合併症の病態 に深く関与するものとして知られている。これは生体 内のタンパク質が高血糖状態に長くさらされることに よると考えられており，不可逆的に生成，蓄積された AGEs が「高血糖の記憶」として 10 年後においても合 併症の頻度に影響すると想定されている1)。また AGEs は正常血糖を示す透析患者においても生成の充 進が認められて抢り，原因として酸化ストレスの立進 が考えられている2

一方，AGEs は古くから味や風味に関わるものとし て知られており調理方法により産生量が異なるとされ ているが，この経口摂取された AGEs が循環血中や組 織中で作用し, さまざまな疾患の発症・進展に関わる ことが明らかになってきている ${ }^{5,6)}$.この食事中に含 まれる AGEs は尿毒症物質の吸着剤として知られる AST-120（クレメジン ${ }^{\circledR}$ ) により除去されることが報 告されており, AST-120 の尿毒症に伴う臟器障害の 抑制効果はその結果であることが想定されている7). またわれわれは血液透析患者において, リン吸着薬で あるセベラマー塩酸塩投与により血清 AGEs 濃度が 有意に低下することを報告した ${ }^{8)}$. しかし，セべラ マー塩酸塩の通常投与量では便秘や腹部膨満感を訴え 脱落する例も多く，無視できない大きな問題と思われ
た．そこで今回われわれは腹部症状の出にくい少量投 与を試み, 血清 AGEs 濃度に及ぼす影響を検討した。

\section{I ．対象および方法}

\section{1. 対象とした患者}

3 か月以上安定して週 3 回の血液透析施行中で, リ ン吸着薬として炭酸カルシウムを投与されている患者 を対象とした．血清リン值に影響を与えるものとして 炭酸ランタン，ニセリトロール，アルミニウム含有制 酸郕および塩酸セべラマーを投与されている患者は除 外した。 シナカルセ卜塩酸塩は 3 か月以上投与され安 定している場合はそのまま継続とした。

今回の研究は倫理委員会にて承認を受け，患者に対 し書面で説明を行い, 承諾を得た 35 例を対象として 研究を開始した．この 35 例中 5 例が便秘や腹部膨満 感のため途中で脱落した。 また 6 例が測定上の問題 で, 3 例が転院のため除外され, 残りの 21 例で 24 週 間経過を観察し結果を解析した。この 21 例の内訳は 男性 11 例, 女性 10 例, 年齢 $65.6 \pm 9.5$ 歳, 透析歴 $89.1 \pm 83.8$ か月, 原疾患として慢性系球体腎炎 8 例, 腎硬化症 6 例，糖尿病性腎症 5 例，多発性のう胞腎 2 例であった。

\section{2. 透析方法}

対象とした患者に扔いて, 研究開始の 3 か月前から 終了までの間に透析液, ダイアライザーおよび透析時 間に変更はなかった．また透析液中のエンドトキシン 濃度は月 1 回定期的に測定しているが，すべて感度以 下であった。 


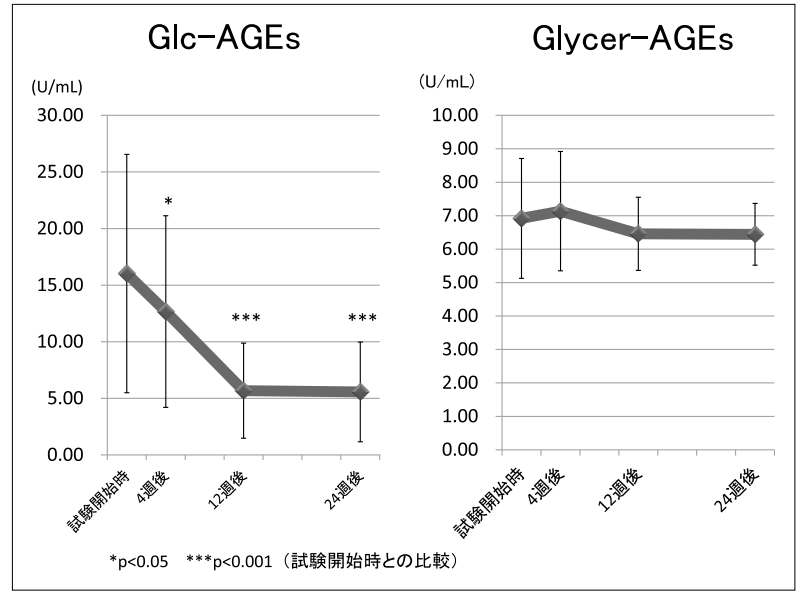

図 1 血清 Glc-AGEs 值および Glycer-AGEs 値の推移

\section{3. セベラマー塩酸塩の投与方法}

従来の炭酸カルシウムの投与量は変更せず，セベラ マー塩酸塩 1 回 $0.5 \mathrm{~g}$ を 1 日 3 回上乗せ投与した. 便 秘に対しては既報のとおり D-ソルビトールを適宜投 与した. 血清リン值のコントロールのため炭酸カルシ ウムを適宜増減した。

\section{4. 生化学的検査}

血清 AGEs 濃度は食品中に多く含まれる glucose 由 来のものを Glc-AGEs, 生体内で生成される glyceraldehyde 由来のものを Glycer-AGEs と命名し，セべラ マー塩酸塩投与開始時, 4 週後, 12 週後および 24 週後 に測定した．方法は既報のとおり ${ }^{9,10)}$ であり，各々の AGEs 特異抗体を用いた競合 enzyme-linked immunosorbent assay（ELISA）法により測定した. 用いら れた抗 AGEs 抗体は既存構造の carboxymethyllysine (CML) やペントシジン, ピラリン, イミダゾロンな どは認識せず，各々の AGEs を特異的に認識するもの である.なお, $1 \mathrm{U}$ は $1 \mu \mathrm{g}$ の Glc-AGE-BSA あるい は Glycer-AGE-BSA 標準品に対応する AGEs 量と定 義した。 また，Glc-AGEs が実際セべラマー塩酸塩に より吸着されるかin vitroで実験を行った。 方法は $0.2 \mathrm{mg} / \mathrm{mL}$ Glc-AGEs の $50 \mathrm{mM}$ リン酸緩衝液（pH 7.4） $1 \mathrm{~mL}$ 中にセベラマー塩酸塩 $50 \mathrm{mg}$ を添加し, $37^{\circ} \mathrm{C}$ で 3 時間ローテーターを用いて回転吸着させた. 3 時間後, 遠心分離により得られた上清中の GlcAGEs 量を測定し吸着率を算出した。 セベラマー塩酸 塩の吸着率は $94.3 \%$ であり, 同様の方法で測定したク レメジン®では $23.8 \%$ であった.

血清カルシウムおよびリン值は 2 週ごと, また総コ レステロール, 中性脂肪, HDL コレステロールおよび インタクト PTH 值は 4 週ごとに測定した．血清脂質 は食後採血のため non-HDL コレステロール（総コレ

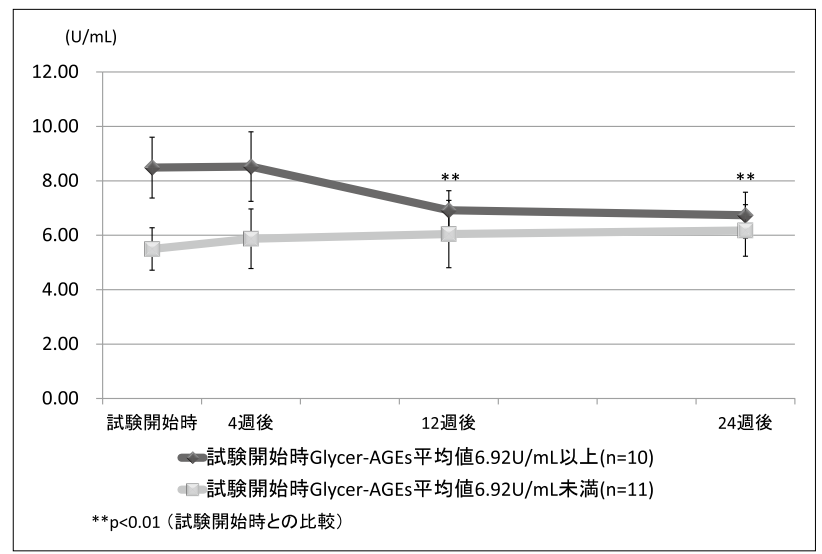

図 2 血清 Glycer-AGEs 值の推移

試験開始時の血清 Glycer-AGEs 值の平均值で 2 群に分け推 移を検討した。高值群で有意に低下した。

ステロール-HDL コレステロール）を算出し，動脈硬 化惹起性コレステロールとして経過を検討した。採血 は週 3 回透析（月, 水, 金もしくは火, 木, 土）の週 はじめに行った。

\section{5. 統計学的検討}

值は平均 $\pm \mathrm{SD}$ で表し, 統計解析は対応のある $T$ 検 定を用いた. $\mathrm{p}<0.05$ を統計学的有意とした。

\section{II. 結 果}

血清 Glc-AGEs 值はセベラマー塩酸塩投与開始時 $16.03 \pm 10.53 \mathrm{U} / \mathrm{mL}$ で, 4 週後は $12.67 \pm 8.47 \mathrm{U} / \mathrm{mL}$ と有意に低下した. 12 週後には $5.68 \pm 4.20 \mathrm{U} / \mathrm{mL}$ と さらに低下し 24 週後も $5.57 \pm 4.40 \mathrm{U} / \mathrm{mL}$ と同様の レベルを維持した. 一方, 血清 Glycer-AGEs 值は開 始時 $6.92 \pm 1.79 \mathrm{U} / \mathrm{mL}$ で, 24 週後まで有意な変化は 認めなかった（図 1).この Glycer-AGEs 值に関して 平均值の $6.92 \mathrm{U} / \mathrm{mL}$ で 2 群に分け, 高值群と低值群 におけるセべラマー塩酸塩の効果を検討した. 高值群 ではセベラマー塩酸塩投与開始時 $8.49 \pm 1.12 \mathrm{U} / \mathrm{mL}$ であり， 4 週後は $8.52 \pm 1.28 \mathrm{U} / \mathrm{mL}$ と有意差は認め なかったが, 12 週後に $6.92 \pm 0.72 \mathrm{U} / \mathrm{mL}$ と有意に低 下し 24 週後も同様のレベルを維持した. 低值群は開 始時 $5.50 \pm 0.78 \mathrm{U} / \mathrm{mL}$ であり, 24 週後は $6.18 \pm 0.95$ $\mathrm{U} / \mathrm{mL}$ と有意差は認めず同様のレベルで経過した（図 2). 同様にGlycer-AGEs 高值群と低值群における Glc-AGEs 值の推移を検討した. 高值群の Glc-AGEs 值は試験開始時 $22.48 \pm 11.47 \mathrm{U} / \mathrm{mL}$ であり, 低值群 では $10.16 \pm 4.89 \mathrm{U} / \mathrm{mL}$ であった．高值群ではセべ ラマー塩酸塩の投与により Glc-AGEs 值は 4 週後よ り有意に低下した。一方, 低值群においても 12 週後 に有意に低下したが, その差は高值群に比し軽微で 
あった（図 3).

血清脂質では総コレステロール值が開始時 $160 \pm 27$ $\mathrm{mg} / \mathrm{dL}$ であり, 4 週後には $149 \pm 24 \mathrm{mg} / \mathrm{dL}$ と有意に 低下し，24 週後も $146 \pm 23 \mathrm{mg} / \mathrm{dL}$ と持続して有意な 低值を示した. Non-HDL コレステロール值も開始時 $111 \pm 29 \mathrm{mg} / \mathrm{dL}$ から 4 週後 $94 \pm 24 \mathrm{mg} / \mathrm{dL}$ と有意に 低下し，24 週後も $92 \pm 15 \mathrm{mg} / \mathrm{dL}$ と持続して有意な低 值を示した. HDL コレステロール值は開始時 $49 \pm 12$ $\mathrm{mg} / \mathrm{dL}$ から 4 週後 $55 \pm 15 \mathrm{mg} / \mathrm{dL}$ と有意に上昇し,

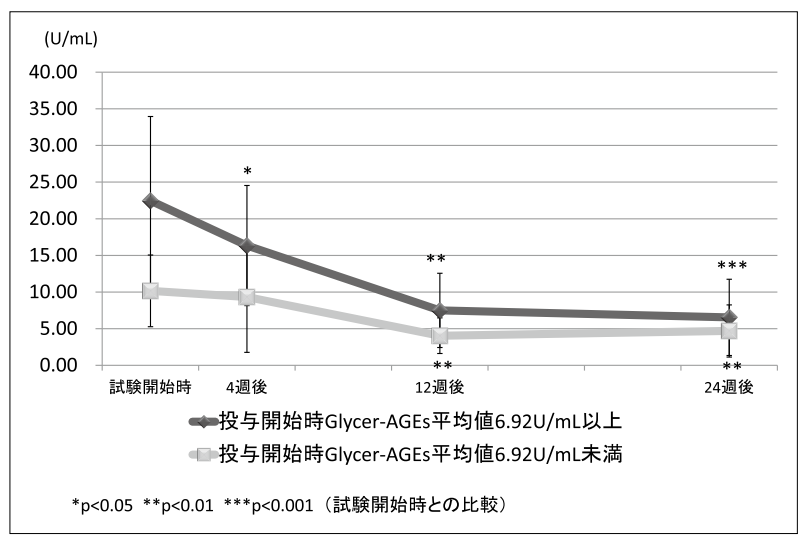

図 3 血清 GIc-AGEs 值の推移

試験開始時の血清 Glycer-AGEs 值の平均值で 2 群に分け推 移を検討した

高值群では 4 週後より有意に低下した．低值群でも 12 週後 に有意に低下したがその程度は高值群に比し軽微であった。
24 週後も $54 \pm 18 \mathrm{mg} / \mathrm{dL}$ と持続して有意な高值を示 した. 一方, 中性脂肪值に有意な変化は認められな かった（図 4)

血清リン值はセベラマー塩酸塩 $1.5 \mathrm{~g} /$ 日を上乗せ 投与したため, 開始時 $6.0 \pm 1.2 \mathrm{mg} / \mathrm{dL}$ から 4 週後 $5.2 \pm 0.8 \mathrm{mg} / \mathrm{dL}$ と有意に低下し, 24 週後も $5.1 \pm 1.3$ $\mathrm{mg} / \mathrm{dL}$ と持続して有意な低值を示した. 血清カルシ ウム值に有意な変化は認めなかった (図 5). インタク 卜 PTH 值は開始時 $140 \pm 128 \mathrm{pg} / \mathrm{mL}$ で，24 週後 196 $\pm 197 \mathrm{pg} / \mathrm{mL}$ と有意な上昇を認めた（図 6).

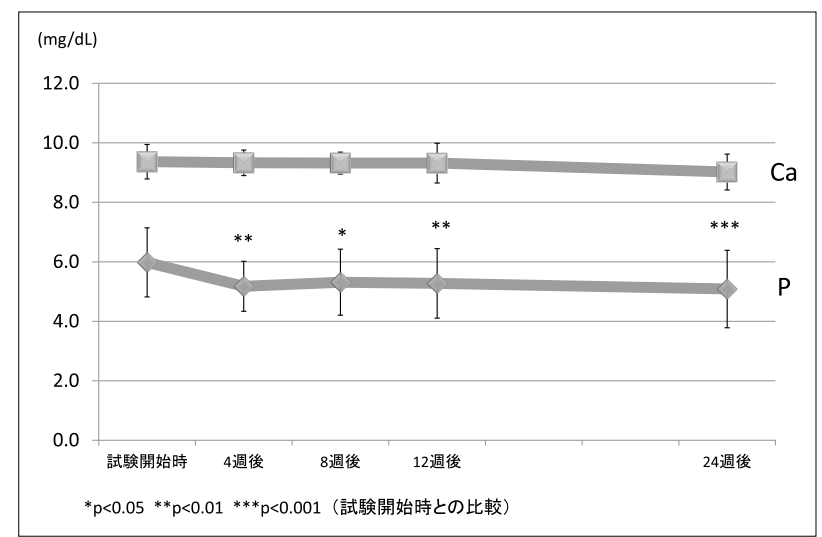

図 5 血清カルシウム値およびリン値の推移

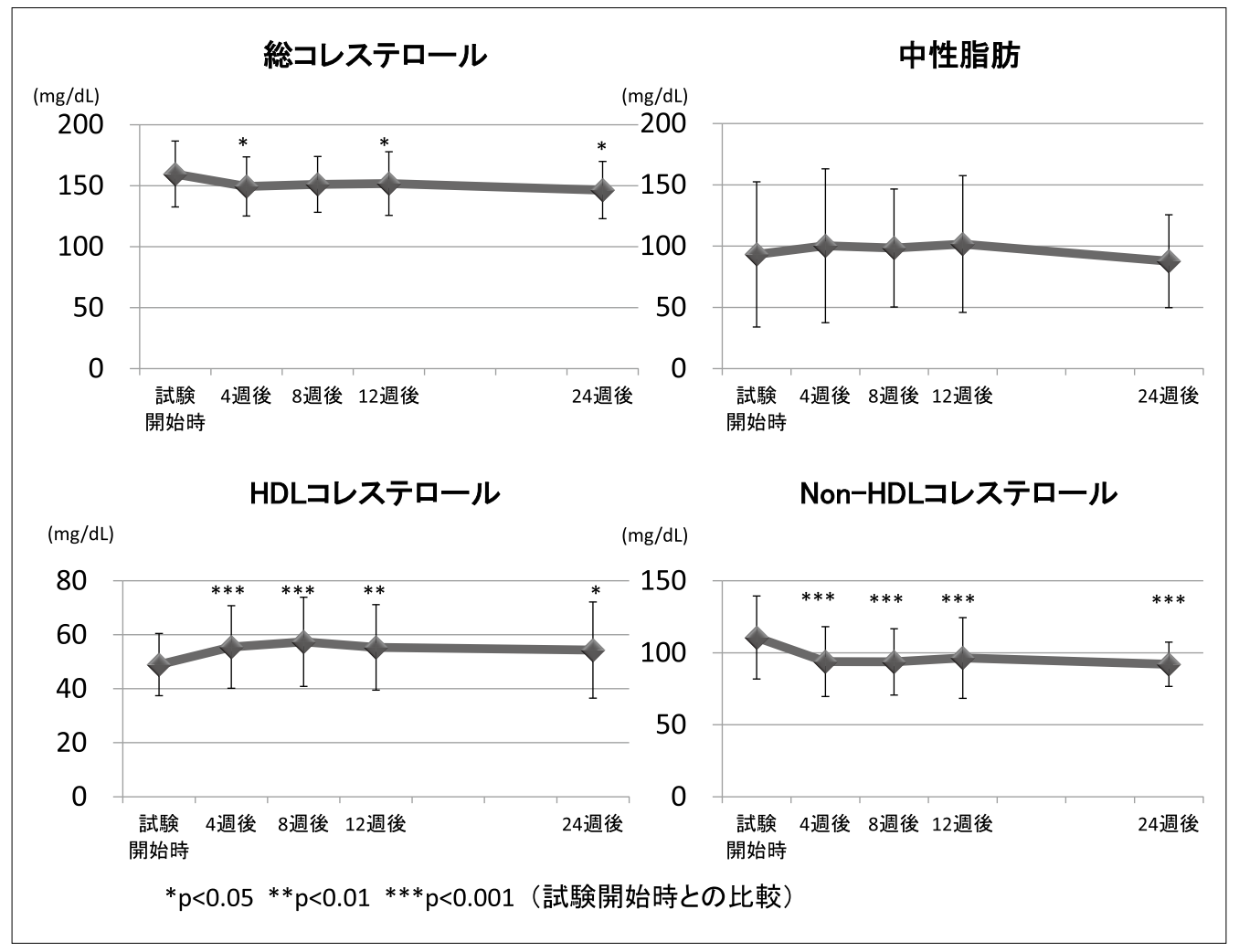

図 4 血清脂質値の推移 


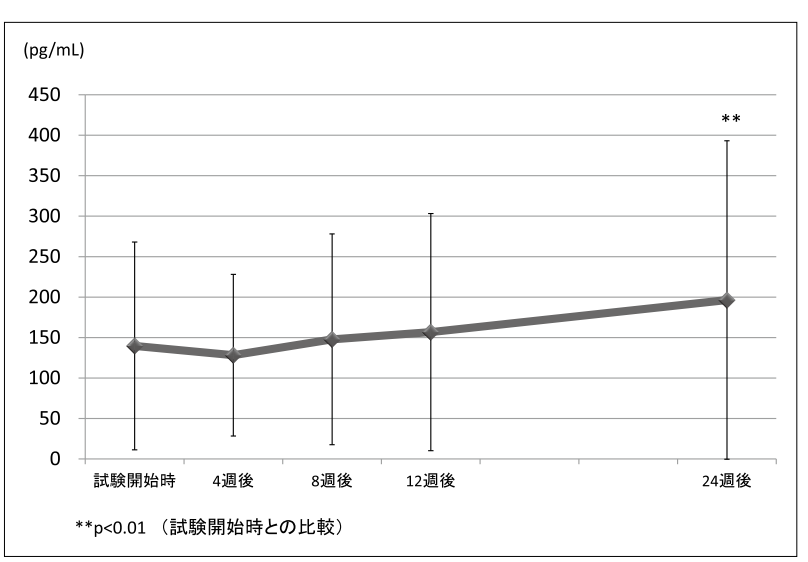

図 6 血清インタクトPTH 值の推移

\section{III. 考 察}

AGEs の生成および蓄積は糖尿病や慢性腎不全環境 下で促進されることが知られており，高血糖や酸化ス トレスが大きく関与するとされている AGEs は細胞表面の受容体 (receptor for AGEs : RAGE）と結合することにより細胞内酸化ストレスを 増大させ，さまざまなサイトカインや増殖因子の分泌 を促進させ炎症反応を惹起するとされている. 一方, 酸化ストレスの亢進そのものが AGEs の生成を促進 することも報告されており ${ }^{2 \sim 4)}$, 酸化ストレスえ進と AGEs 生成は悪循環を形成してますます心血管病変を 進展させていくものと思われる.

今回われわれが検討した AGEs は, 食品中に多く含 まれる glucose 由来 AGEs（Glc-AGEs）と生体内で生 成される glyceraldehyde 由来 AGEs (Glycer-AGEs) である. Takeuchi らはこのうち Glycer-AGEs が RAGE を介して糖尿病の血管合併症などの発症, 進展 に強く関わっていることを解明し, toxic AGEs (TAGE) と命名し TAGE 病因説を提唱している ${ }^{11 \sim 13)}$. すなわち腎不全や糖尿病環境下においてアルデヒドや カルボニル化合物の産生が増大した“カルボニルスト レス状態”では，蛋白質がこれらの化合物と非酵素的 に反応し種々の AGEs が生成されるものと考えられ る.このうち CML, ペントシジンやピラリンなど RAGEと結合活性を持たず生理活性を示さないnontoxic AGEs は, 化学反応性の高いカルボニル化合物 を蛋白質がトラップして無毒化するという，いわば生 体防御反応として機能していると考えられる。これに 対し Glycer-AGEs はRAGE と結合して細胞内酸化ス トレスを増大し, 種々のサイトカインや増殖因子の分 泌を促進し, 結果として生活習慣病の原因になるもの
と推察されている. また高 Glc-AGEs 含有飲料を正 常ラットに経口投与し TAGE-RAGE 系への影響を検 討した結果, ラット肝において RAGE や血管内皮増 殖因子（vascular endothelial growth factor : VEGF） 遺伝子の発現が増大し, 肝での Glc-AGEs および TAGEの蓄積が認められたとしている坟。この VEGF は血管新生活性とともに強い血管透過性立進 活性を持つため, 糖尿病性網膜症や腎症の発現への関 与が考えられている.すなわち食事性 AGEs の過剩 摂取は肝細胞内の代謝を乱す結果, TAGE 前駆体のグ リセルアルデヒドの生成が増大し肝細胞内や血中での TAGE レベルが増加して TAGE-RAGE 系を介した 酸化ストレスからさらなる TAGE 生成を招くという 悪循環をひき起こし, 血管障害を惹起することが想定 される.

これらのことより食事由来の AGEs を減らすこと で臓器障害を抑制できる可能性が示唆されるが, Ue$\mathrm{da} ら^{7)}$ はAST-120 (クレメジン $\left.{ }^{\circledR}\right)$ 投与により血清 AGEs 濃度が低下することを見い出し，これが尿毒症 の進行を抑制し臓器保護効果を発揮している可能性に ついて報告している. 今回われわれが着目したリン吸 着薬であるセベラマー塩酸塩は, 炭酸カルシウムに比 し LDL コレステロールや高感度 CRP を有意に低下 させ，またインスリン抵抗性も改善させることが報告 されている ${ }^{15 \sim 18)}$ 。すなわち単にリンを吸着するだけで なく, いわゆる pleiotropic 作用により動脈硬化や血管 石灰化の抑制など生命予後の改善につながることが想 定されている.そこでわれわれは透析患者に炭酸カル シウムに代えてセベラマー塩酸塩を $4.5 \mathrm{~g}$ /日投与し, 血清 AGEs や脂質濃度の変化を検討した ${ }^{8)}$. その結 果, 食事中の Glc-AGEs が吸着除去されることにより 強毒性の Glycer-AGEs の産生も低下することを認 め, また non-HDL コレステロールも有意に低下し， 炎症の指標である高感度 CRP も低下傾向を認めた. これらの結果から，七ベラマー塩酸塩投与により透析 患者の心血管病変の軽減が期待できると考えられた。 実際 Kakuta ら ${ }^{19)}$ はセべラマー塩酸塩の投与により AGEの蓄積と冠動脈石灰化の軽減を報告している.

しかし, 日本人に対し欧米人並みの量のセベラマー塩 酸塩を投与すると便秘が大きな問題になり，実際われ われの検討でも 1 日 $4.5 \mathrm{~g}$ の投与で 14 例中 3 例の患 者が便秘のため途中脱落した.

そこで今回，便秘を起こしにくい投与量として 1 日 $1.5 \mathrm{~g}$ のセベラマー塩酸塩を追加投与し検討した. そ の結果, 便秘のため脱落したのは 35 例中 5 例であっ たが 1 日 $4.5 \mathrm{~g}$ 投与時に比し減少した. Glc-AGEs 值 
は投与 4 週目より有意に低下したが, Glycer-AGEs 值には変化を認めなかった。しかし Glycer-AGEs 值 に関し平均值で 2 群に分けて検討したところ, 低值群 では有意な変化を認めなかったが，高值群ではセべラ マー塩酸塩投与 12 週後から Glycer-AGEs 值の有意 な低下を認めた。この点に関し，Glycer-AGEs が高 值の群では, 前報8) と同様に酸化ストレスの軽減とと もに Glc-AGEs 值の低下に伴う代謝の変化で GlycerAGEs 值が低下する機序が考えられた。一方，Glycer-AGEs が低值の群はすでに正常值に近いレベルで あり ${ }^{20)}$ ，また Glc-AGEs も低值でかつセべラマー塩酸 塩投与による Glc-AGEs 值の低下も軽微なため Glycer-AGEs 值が変化しにくいと考えられた．さらにセ ベラマー塩酸塩の投与量自体も少量であり酸化ストレ 又軽減効果が減弱している可能性も考えられた。しか し，今回対象とした患者は前報に比し高齢で $\mathrm{Glc}^{-}$ AGEs も低值であったが，セべラマー塩酸塩投与で Glc-AGEs 值がより低下した群では Glycer-AGEs 值 も有意に低下して扔り，セべラマー塩酸塩の少量投与 であっても十分有効であると思われた。 また血清脂質 に関して，前報と同じく今回の検討でも non-HDL コ レステロール值は有意に低下した。一方で HDL コレ ステロール值は有意に上昇し, セベラマー塩酸塩投与 による動脈硬化抑制作用がさらに期待できる結果で あった。

今回の検討でセベラマー塩酸塩 $1.5 \mathrm{~g} /$ 日の追加投 与で血清リン值は約 $0.8 \mathrm{mg} / \mathrm{dL}$ 低下した。 もちろん この量では血清リン值を目標值にコントロールするこ とは極めて困難であり, 炭酸カルシウムの併用が必要 である。しかし生体に対するカルシウムの過剩負荷は 生命予後を悪化させることが知られておりり ${ }^{21,22)}$ ，可能 な限りセべラマー塩酸塩に変更することが有用である と思われるが，今回の検討でそれがたとえ 1 日 $1.5 \mathrm{~g}$ と少量であっても十分意義があると思われた。

以上, セベラマー塩酸塩は $1.5 \mathrm{~g} /$ 日という少量投与 であっても血清 AGEs 濃度の低下や血清脂質の改善 などにより透析患者の血管合併症を抑制できる可能性 が考えられた．生体へのカルシウム負荷軽減のために もまず服薬可能な量のセベラマー塩酸塩を基礎薬とし て投与し，血清リン值のコントロールに不足する分を 炭酸カルシウムで補うという発想の転換があってもよ いと考えられた，そして症例数を増やして実際の血管 合併症に対する影響を検討する必要があると思われ る.

\section{結語}

少量のセベラマー塩酸塩投与であっても血清 AGEs 濃度の有意な低下や血清脂質の改善を認めた。これに より透析患者の血管合併症進展の抑制が期待される.

\section{文献}

1) Nathan DM, Cleary PA, Backlund JY, Genuth SM, Lachin JM, Orchard TJ, Raskin P, Zinman B: Intensive diabetes treatment and cardiovascular disease in patients with type 1 diabetes. $\mathrm{N}$ Engl J Med $353: 2643-2653,2005$

2) Miyata $T$, Ueda $Y$, Shinzato $T$, Iida $Y$, Tanaka $S$, Kurokawa K, van Ypersele de Strihou C, Maeda K : Accumulation of albumin-linked and free-form pentosidine in the circulation of uremic patients with endstage renal failure : renal implication in the pathophysiology of pentosidine. J Am Soc Nephrol 7 : 11981206, 1996

3) Miyata T, Fu MX, Kurokawa K, van Ypersele de Strihou C, Thorpe SR, Baynes JW : Autoxidation products of both carbohydrates and lipids are increased in uremic plasma : Is there oxidative stress in uremia? Kidney Int $54:$ 1290-1295, 1998

4) Nishikawa $T$, Edelstein $\mathrm{D}, \mathrm{Du} \mathrm{XL}$, Yamagishi S, Matsumura T, Kaneda Y, Yorek MA, Beebe D, Oates PJ, Hammes HP, Giardino I, Brownlee M : Normalizing mitochondrial superoxide production blocks three pathways of hyperglycaemic damage. Nature 404 : 787-790, 2000

5) Yamagishi S, Ueda S, Okuda S : Food-derived advanced glycation end products (AGEs) : a novel therapeutic target for various disorders. Curr Pharm Des $13: 2832-2836,2007$

6) Yamagishi S, Nakamura $K$, Matsui $T$, Noda $Y$, Imaizumi $\mathrm{T}$ : Receptor for advanced glycation end products (RAGE) : a novel therapeutic target for diabetic vascular complication. Curr Pharm Des 14 : 487-495, 2008

7) Ueda S, Yamagishi S, Takeuchi M, Kohno K, Shibata R, Matsumoto Y, Kaneyuki U, Fujimura T, Hayashida A, Okuda S: Oral adsorbent AST-120 decreases serum levels of AGEs in patients with chronic renal failure. Mol Med 12 : 180-184, 2006

8）村本弘昭，北田欽也，武藤寿生，竹内正義：透析患者 における血清終末糖化産物 (AGEs) 濃度一七べラマー 塩酸塩投与の効果一. 透析会誌 $44: 1015-1021,2011$

9) Takeuchi M, Makita Z, Yanagisawa K, Kameda Y, Koike $\mathrm{T}$ : Detection of noncarboxymethyllysine and carboxymethyllysine advanced glycation end products (AGE) in serum of diabetic patients. Mol Med 5 : 
393-405, 1999

10) Takeuchi M, Makita Z, Bucala R, Suzuki T, Koike T, Kameda Y : Immunological evidence that non-carboxymethyllysine advanced glycation end-products are produced from short chain sugars and dicarbonyl compounds in vivo. Mol Med $6: 114-125,2000$

11) Takeuchi M, Yamagishi S: TAGE (toxic AGEs) hypothesis in various chronic diseases. Med Hypotheses $63:$ 449-452, 2004

12) Sato T, Iwaki M, Shimogaito N, Wu X, Yamagishi S, Takeuchi M : TAGE (toxic AGEs) theory in diabetic complications. Curr Mol Med $6:$ 351-358, 2006

13) Takeuchi M, Takino J, Yamagishi $S$ : Involvement of the toxic AGEs (TAGE)-RAGE system in the pathogenesis of diabetic vascular complications : A novel therapeutic strategy. Curr Drug Targets 11 : 1468-1482, 2010

14) Sato $T, W u X$, Shimogaito N, Takino J, Yamagishi S, Takeuchi M : Effects of high-AGE beverage on RAGE and VEGF expression in the liver and kidneys. Eur J Nutr $48: 6-11,2009$

15) Chertow GM, Burke SK, Raggi $P$ : Sevelamer attenuate the progression of coronary and aortic calcification in hemodialysis patients. Kidney Int $62: 245-252,2002$

16) Block GA, Spiegel DM, Ehrlich J, Mehta R, Lindbergh $\mathrm{J}$, Dreisbach A, Raggi P : Effect of sevelamer and calcium on coronary artery calcification in patients new to hemodialysis. Kidney Int 68 : 1815-1824, 2005

17) Yamada K, Fujimoto S, Tokura T, Fukudome K, Ochiai H, Komatsu H, Sato Y, Hara S, Eto T : Effect of sevelamer on dyslipidemia and chronic inflammation in maintenance hemodialysis patients. Renal Fail 27 : 361-365, 2005

18) Shantouf R, Budoff MJ, Ahmadi N, Tiano J, Flores F, Kalantar-Zadeh K : Effects of sevelamer and calciumbased phosphate binders on lipid and inflammatory markers in hemodialysis patients. Am J Nephrol 28 : 275-279, 2008

19) Kakuta T, Tanaka R, Hyodo T, Suzuki H, Kanai G, Nagaoka M, Takahashi H, Hirawa N, Oogushi Y, Miyata T, Kobayashi H, Fukagawa M, Saito A : Effect of sevelamer and calcium-based phosphate binders on coronary artery calcification and accumulation of circulating advanced glycation end products in hemodialysis patients. Am J Kidney Dis 57 : 422-431, 2011

20) Hyogo H, Yamagishi S, Iwamoto K, Arihiro K, Takeuchi M, Sato T, Ochi H, Nonaka M, Nabeshima N, Inoue $\mathrm{M}$ : Elevated levels of serum advanced glycation end products in patients with non-alcoholic steatohepatitis. J Gastroenterol Hepatol 22:1112-1119, 2007

21) Guerin AP, London GM, Marchais SJ, Metivier F : Arterial stiffening and vascular calcification in endstage renal disease. Nephrol Dial Transplant 15:10141021, 2000

22) Goodman WG, Goldin J, Kuizon BD, Yoon C, Gales B, Sider D, Wang Y, Chung J, Emerick A, Greaser L, Elashoff RM, Salusky IB : Coronary-artery calcification in young adults with end-stage renal disease who are undergoing dialysis. N Engl J Med 342 : 1478-1483, 2000 